\title{
Using Pictures Series Technique to Enhance Narrative Writing among Ninth Grade Students at Institución Educativa Simón Araujo
}

\author{
Katia Gregoria Contreras Gutiérrez ${ }^{1}$, Miriam Niño Puello ${ }^{2} \&$ Luis Alberto Pérez Galvis ${ }^{2}$ \\ ${ }^{1}$ Institución Educativa Dulce Nombre de Jesús, Universidad de Sucre, Sincelejo, Colombia \\ ${ }^{2}$ Universidad de Sucre, Sincelejo, Colombia \\ Correspondence: Luis Alberto Pérez Galvis, Institución Educativa Simón Araujo, Universidad de Sucre, \\ Sincelejo, Colombia. E-mail: perezgalvis@yahoo.com
}

\author{
Received: February 10, 2015 Accepted: March 24, 2015 Online Published: April 23, 2015 \\ doi:10.5539/elt.v8n5p45 URL: http://dx.doi.org/10.5539/elt.v8n5p45
}

\begin{abstract}
This study reports an action research on the use of pictures series technique to develop EFL narrative writing among a group of ninth graders at Institución Educativa Simon Araujo. It involves Experimental and Control groups. During the implementation of the strategy the Experiment group was taught writing with picture series technique and the Process-based approach to determine whether the program of intervention achieved the intended results (cause and effect) concerning the research question to resolve the problem of investigation while the Control group was taught only with Process-based approach. After sixteen weeks of instruction, a post-test (achievement test) was administered to both groups to measure the effect of the intervention process. The obtained results through descriptive statistics (Mean) indicated there was a significant difference between the group which was taught through Pictures series technique and Process-based approach over the one which only received Process-based instruction. The researchers conclude that the intervention with Picture series technique improved the overall growth of writing skills, specific to the areas of Transition or logical sequence and Ideas exposure.
\end{abstract}

Keywords: EFL/ESL writing skill, narrative writing, pictures series technique, process-based approach

\section{Introduction}

The main focus of this paper is to share the researchers' experience and the results of an action research in the field of EFL writing, especially with colleagues and teachers interested in developing innovative strategies to teach writing at any level of tutoring. It reports on the use of Picture series technique to improve the narrative writing skill in 20 participants from the ninth grade at Institución Educativa Simón Araujo in Sincelejo, Colombia.

Narrative is the primary means of comprehension and expression of our experience over time, which can be found in every setting of human interaction. In this regard as Abbott (2002) posits; "narrative is present in our lives almost from the moment we begin putting words together" (p. 1). The research focused on the development of narrative writing skills as it is a type of text students are expected to be skilled in according to the National Standards for Foreign Language Learning issued by The Ministry of Education in Colombia. The versatility of narrative writing makes it the most suitable genre to teach in the classroom. Through narrative writing students organize ideas and experiences creatively and imaginatively by combining linguistic, pragmatic and sociolinguistic competences. As illustrated in the following basic writing standards from the ninth and the tenth grade: "I write narratives about personal experiences and events around me" and "I narrate experiences, facts or stories of my interest and the interest of my audience", the learner is requested to use his knowledge about the formal resources to understand and use the language like grammar, syntax, morphology, semantics, which means his linguistic competence in concrete communicative situations (pragmatic competence).

Another important component, which provides the fundamental basis for developing narrative writing in this study, is the Process approach. Conceptualizing process approach is a matter of what it implies for teaching and learning writing rather than what its definition is. Nunan (1999) introduces process approach according to the steps involved in drafting and redrafting a piece of work. In Raimes (1983) there is not an express definition of Process approach but a number of criteria the learner must observe to write. For instance, Raimes states that 
writing is a matter of decision making, it means the student decides "how to begin and how to organize the task" (p. 10). Secondly, the student requires time and proper feedback from its readers (teachers or classmates) "to discover new ideas, sentences and words as he plans and writes his first drafts" (p. 10). On the other hand, White and Arndt (1991) cited in Nunan (1999) view process writing as a "complex, cognitive process that requires intellectual effort over a considerable period of time" (p. 274). These cognitive processes have an enormous impact on what the writer does while writing, instead of what the final product may look like (Kroll, 1990)

Based on the above, Process approach was selected as the most appropriate approach to teach narrative writing. Through Process approach, students gradually learn how to create texts by mastering cognitive writing strategies like pre-writing, drafting, revising, editing and publishing their own written work (Graves, 1994). Additionally, implementing Process approach matches a series of communicative competences (linguistic, pragmatic, and sociolinguistic) students need in order to write particular narrative text types according to the National Standards for Foreign Language Learning. For instance, the following three writing standards for the ninth grade "I organize short coherent paragraphs, taking into account formal elements of language as spelling and punctuation", "I edit my writings in class, taking into account spelling, correct vocabulary and grammatical structures" and "I use plans represented on maps or diagrams to develop my writing" are coherent with most cognitive models of writing (Flower \& Hayes, 1981; White \& Arndt, 1991; Graves, 1994)

Finally, this paper is an attempt to show the benefit of including Picture series technique in a writing classroom already utilizing Process approach. The literature reviewed by the researchers regarding picture in language teaching (Raimes, 1983; Wright, 1990; Hill, 1990; Bowen, 1991) maintain that incorporating picture to language teaching and learning has positive effects on the improvement of learners' communicative skills. These resources help teachers to contextualize language by connecting the classroom with the world outside its walls. They also encourage students to use the target language by providing support or a reference point to write or talk about. In this regard, Wright (1990) affirms that pictures "contribute to: 1) interest and motivation; 2) a sense of the context of the language; and 3) a specific reference point or stimulus" (p. 2).

The adaptability of pictures to any kind of communicative tasks is reported by Raimes (1983) who states that "pictures provide a shared experience for students in the classroom, a common base that leads to a variety of language activities" (p. 28). This feature of pictures may be used to design tasks focused on developing narrative writing. For instance, a teacher may implement picture strip sequence, cartoon strips or photo story strips in the following basic writing standard for the third grade "I write descriptions and short stories based on a sequence of images" to fulfill a goal related to storytelling or writing about processes.

\subsection{Statement of the Problem}

In native language environments, productive skills develop differently. Writing, unlike speaking, involves a process of formal learning, while speaking develops naturally through a process called "acquisition" (Krashen, 1987). Although they undertake a process of formal learning of writing, most native speakers never master this skill (Nunan, 1999). In the same line, Nunan also affirms that when facing writing the "challenges for second language learners are enormous" (p. 271). In addition, the researchers dares to add, based on his own experience, that in foreign language teaching settings, the challenges for students to develop writing skills are even the most demanding but with the lowest levels of achievement.

In the educational setting where this study has been carried out, most of the students face serious problems to write in English, in spite of the emphasis the school has given to enhance productive skills in the foreign language class. As a result, writing has the lowest percentage of achievement of all the communicative skills. Beside the academic records, findings from the pre-test scores revealed that most participants had difficulties in writing short texts related to specific writing standards. These results evidenced a mismatch between the participants' writing competence for the ninth grade according to the National Standards for Foreign Language Learning and the scores obtained from the standardized tests applied in the classroom.

The situation described above encouraged the researchers to explore alternative strategies to approach the above mentioned problem. A review of the literature led to the decision of adopting and implementing Picture series technique to support the processes of teaching narrative writing. Thus, the researchers expected the learners improve their writing skill and develop a higher degree of involvement in their learning process.

\subsection{Research Question}

Could the narrative writing skill be improved in a group of ninth graders in A2 (CEFR) English proficiency level through the use of Picture series technique? 


\subsection{Objective}

To determine whether Picture series technique could improve the narrative writing skill in a group of ninth graders in A2 (CEFR) English proficiency level.

\section{Background of the Study}

\subsection{The Writing Process}

Teaching EFL writing differs from teaching other language skills. Writing, unlike speaking, fosters a different connection between the writer and the reader. In this regard, Díaz (1999) affirms that "the competence of producing and understanding written discourses is different from producing and understanding oral discourses" (p. 3). The most obvious dissimilarity between writing and speaking has to do with the processes writers and speakers go through. In face to face interaction, there is a little time between production and reception: while in writing the mental process to produce a text involves the chance to write and edit ideas (Harmer, 2004). Harmer also affirms that in writing, the "final product is not nearly so instant, and as a result, the writer has a chance to plan and modify what will finally appear as the finished product" (p. 8). This attribute makes writing a more complex skill to master since learning to write, unlike speaking, requires systematic instruction and practice.

Today view of writing as a main skill is the result of its evolution in research and teaching. During the 1970's, writing was a subsidiary skill for grammar courses. Extensive, repetitive drill exercises were implemented to reinforce speech, through the stress of the mastery of grammatical and syntactic forms (Richard, 1990). This orientation of writing goes back to the 60's when behaviorist psychology and structural linguistic theorized language teaching as a hierarchical transmission of knowledge from the teacher to students and language learning was the result of the reinforcement of oral habits (Silva, 1990). Essentially, from this perspective, writing was a product constructed which resulted from imitating models and patterns provided by the teacher. This utilitarian view of writing derived from the audiolingual method (Reid, 2001), which theory and practice revolved around producing error-free sentences. Under this perspective, language learners were expected to produce accurate oral discourses after rehearsing clue "communicative" grammar structures.

In the late 70's and the early 80 's, the emergence of Communicative Language Teaching (CLT) brought an important stimulus for changing the way we teach language today. ESL/EFL writing begun to be a subject of research, as a result, it experimented important shifts in its teaching. The most important was to recognize it as a main system for the expression of meaning against the old utilitarian paradigm. ESL/EFL writing teaching today focuses more on the stages for developing successive drafts of a text rather than on releasing a perfect final product in just one writing (Nunan, 1999). This new perspective of writing differs from the product oriented approach in which the learners focus on tasks they imitate, copy, and transform from models provided by the teacher and/or the textbooks" (Nunan, 1999, p. 272).

Several scholars emphasize on the cognitive processes that writing involves (Graves, 1994; Raimes, 1983; Flower \& Hayes, 1981; White \& Arndt, 1991). The writing model designed by Flower and Hayes (1981) implies looking at writing as a complex-cognitive process where a non-linear procedure leads to a final refined written product. Flower and Hayes' cognitive model of writing is probably the most widely accepted model by L2 (Figure 1). Building on this work, Raimes, (1992) keeps that it is a priority of teachers to develop their students' metacognitive awareness of the strategies they use to write, that is, giving their students support and feedback throughout the process of writing. 


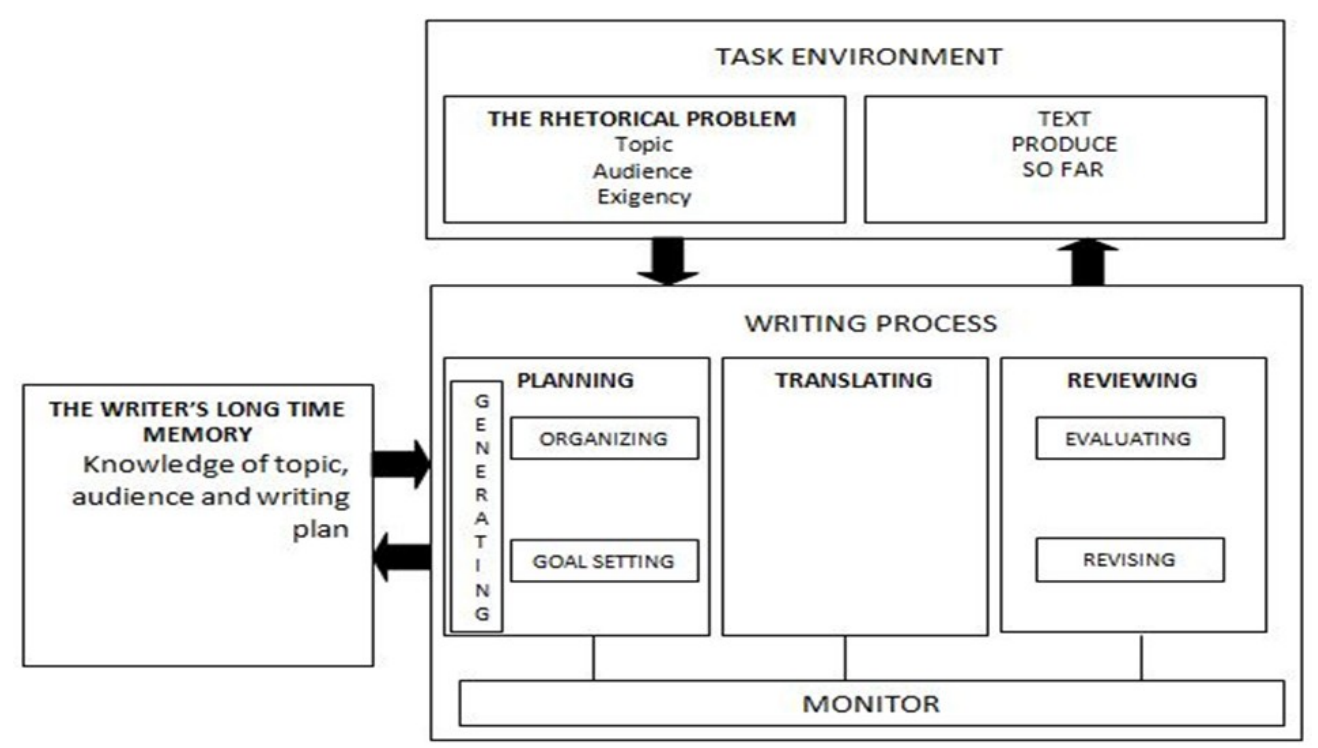

Figure 1. Flower and Hayes' congnitive process theory of writing

In the same line as above, Hedge (2005) states that writing is a complex process where several operations interact and occur simultaneously. Hedge's cognitive vision of writing is in line with White and Arndt (1991) who introduce a clear and practical view of process writing. They suggest that writing is a complex-cognitive process that requires intellectual effort over a considerable period of time. White and Arndt identified six procedures before producing a final draft as Figure 2 indicates.

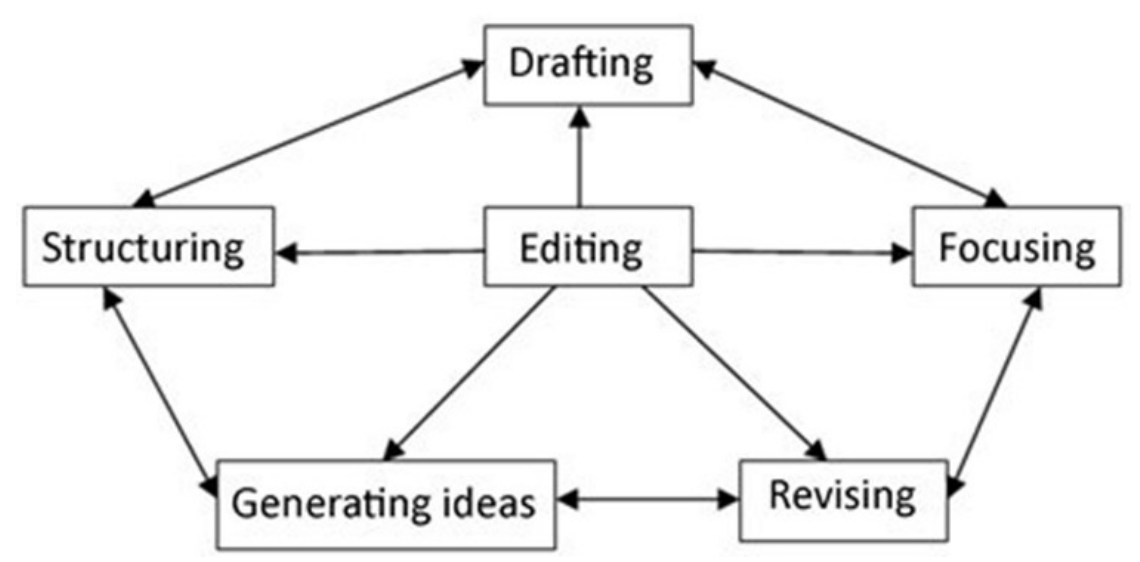

Figure 2. Procedures involved in producing a written text

The diagram above explains the cyclical nature of how the process approach helps learners to develop skills to produce a written text. These procedures are connected to one another so that the learner can move freely through the creative process of arranging ideas on a piece of paper. Likewise, Graves (1994) also identified five stages of the writing process: prewriting, drafting, revising, editing, and publishing/sharing. These stages do not take place in a linear manner; rather, they involve recurring cycles.

Drawing on already existing research in the field of writing as a process, Sasaki (2000) investigated the writing processes of Japanese EFL learners with three different levels of second language writing ability: expert writers, professional people whose work included regularly writing English papers, the next two groups of participants were college freshmen divided according to their level of proficiency in more skilled students and less skilled students. Sasaki study compared the results obtained in terms of writing quality gain and strategy use of the groups after six month of instruction on process writing. Findings revealed that after the six month treatment, 
there was a meaningful gain in the writing process of the more and less skilled writers, who began to use strategies related to writing process and improve the quality of their writing. According to Sasaki's study the expert group apparently "stuck" to their pre-existing writing expertise, situation which did not allow the researchers to arrive to a definite conclusion in term of strategy gain.

Hasan and Akhand (2010) presented the findings of an interventionist study designed to examine the effects of product and process approach to writing on learners' performance. Hasan and Akhand instructed one group with process approach and the other with product approach. Then, they applied a collaborative approach (Genre approach) for both groups. The observation of the intervention and the analysis of the results showed revealing findings when applying product and process approach in the early stages of the intervention: the students from the group under the product approach showed a kind of fossilization in their composition as they imitated model writing or recalled their previous knowledge of writing. It seemed that this group did not develop new writing strategies to deal with the writing tasks. On the other hand, it was observed that the students from the group under the process approach experimented difficulties in brainstorming and organizing their ideas cohesively as they were not familiar with the method. Even though, with time the students managed to cope with the method and get their ideas organized. Unfortunately, as the group from the product approach, the students from this group retreated back to their old fashioned paragraph writing. Hasan and Akhand also reported that in spite of the drawbacks students experienced during the intervention, there was corroborating evidence to support that the treatment worked for some kind of texts. For example, for business report writing, students felt comfortable in product approach as the task consists of the fixed layout, style and organization. In case of teaching narrative or argumentative essay, students were more comfortable with process approach. Such evidences led the researchers to suggest a collaborative approach; it means the combination of product and process approach according to the needs of learning may be adapted by teachers in an EFL/ESL classroom.

All in all, it is clear from the review of the literature presented in this section that the writing skill is a cognitive process (White \& Arndt, 1991) that involves the activation of a series of non-linear mental operations (Hedge, 2005) to organize and arrange the ideas on a piece of paper.

\subsection{Contributing Aspects of Pictures in Teaching Language Skills}

The use of pictures and other visual aids is consistently supported by studies that demonstrate the versatility of this type of resources in language teaching and learning. To begin with, it is necessary to turn from the concept of learning styles as the primary foundation of the theory related to pictures in language teaching. Learning styles are defined as the manner in which individuals perceive and process information in learning situations (Brown, 2000). Brown's definition seems to be very simplistic, even though it involves an accurate concept of what learning styles denote. From Brown's definition it is understood that we have personal ways or manners to process the information perceived by the senses (sight, hearing, taste, smell and touch) which allow us to recognize and understand the world around us (sizes, colors, forms, flavors, sounds, scents, etc). On the same subject, Fleming (2001) defines learning style as preferred ways individuals gather, organize, and think about information. Fleming identified three main or basic learning styles: visual, auditory, and kinaesthetic (known as VARK) based on people's preferences in learning situation.

People's learning style is either or a combination of auditory, visual, or kinesthetic in terms of the way they learn best. In spite of these combinations, people commonly have a preferred learning style over the others. Research reports that many students are more visual and tactile/kinesthetic or mixed than auditory (R. Dunn \& K. Dunn, 1992; Barbe \& Milone, 1981). This evidence supports that we live in a world that is visually oriented. Most of the information that our brains process comes from non-verbal stimuli (images) and even verbal information is better processed when is accompanied with visual stimuli. The way in which individuals perceive and process information from the surrounded world is called visual literacy.

The adoption of such a learning style perspective is central to support the use of picture technique to teach the writing skill. The essence of teaching narrative writing by using picture series lies upon the fact that they provide a sense of context of the language by bringing the world into the classroom Wright (1990). Pictures contextualize the comprehensive skills (reading and listening) allowing students understanding concepts, recognizing details, visualizing vocabulary, understanding sequencing, and supporting listening. They also contribute to productive skills (speaking and writing) by stimulating and providing information to be referred in conversation, discussion and storytelling (Wright, 1990).

Mansourzadeh (2014) investigated and compared two techniques of teaching vocabulary to young Iranian EFL learners, pictures and audio-visual aids to find out if any of them was more effective than the other. Findings indicated that there was more inferring and retention of the meanings of unknown words from pictures than the 
audiovisual aids technique. Another important research was carried out by Konomi (2014) who studied the effects of visual materials (from printed visual material like posters and pictures to videos) used in the EFL classroom when teaching vocabulary to young learners. Konomi focused her inquiry on four main issues: how teacher use visual materials, sources where these materials come from, pupils' attitudes towards visual materials used when learning vocabulary, and teachers' attitudes towards visual materials used in teaching new vocabulary. Her finding revealed, that in spite of the availability of video resources, teachers preferred to use pictures, posters and postcards more often (58.4\%) than other type of material to teach vocabulary. Regarding young learners' attitudes toward visual materials, Konomi found that students who were taught vocabulary using posters and flash cards were more successful in the pre-test and post-test.

The effectiveness of pictures in writing may also be observed in their use to promote a variety of texts, from basic simple sentences to the production of more complex paragraphs about almost any kind of topics and genres. In her master thesis Alvarez (2013) investigated about applying scaffolding strategies with pictures and learning logs to foster self-efficacy in descriptive writing. She carried out a qualitative research with a group of students aged 16-17 years old from the tenth grade in a public school in Chía, Cundinamarca, Colombia. Her finding revealed that implementing scaffolding strategy with learning logs and pictures in the process of instruction fostered self-efficacy in descriptive writing. For Alvarez, both scaffolding strategies used in her research were decisive to determine gain in terms of writing development. In 2014, Aschawir carried out a quantitative study on the development of English narrative writing through series pictures. Aschawir used a Control group and an Experimental group which he implemented series pictures technique with. Aschawir contrasted the results from the post-test and concluded that the Experimental group outperformed the Control group in writing narrative texts as a result of the strategy implemented. In the same line, Sa'diyah (2010) also investigated about improving students' ability in writing a descriptive text through the use of a picture series-aided learning strategy in a public senior high school in East Java, Indonesia. Findings revealed that both, the motivation and the writing performance of the students were positively affected by the implementation of picture series.

Finally, it has been found that students can become more actively involved through the use of visual materials. It has been registered that students seems to be more motivated and involved in the writing tasks when using pictures because these resources provide a stimulating focus for students' attention (Raimes, 1983). In a 2012 paper, Uematsu reviewed important contributions of pictures to language teaching, looking in particular at the motivational factors provided by pictures. Uematsu summarizes that pictures help teachers to teach better and students to learn better. He has also found that pictures have the attribute to engage students in their learning given that they are appealing resources for students.

\section{Research Design}

\subsection{Type of Study}

This experimental study was primarily designed following the principles of action research by Carr and Kemmis (1986). Carr and Kemmis define Action research "as a form of self-reflective enquiry undertaken by participants in social situations in order to improve the rationality and justice of their own practices, their understanding of these practices, and the situations in which the practices are carried out" (p. 162). With this in mind, twenty (20) ninth graders in A2 English level of language proficiency (CEFR) with an average age of 14 evenly distributed in a 50\% female and 50\% male team from a public school in the urban area of Sincelejo, Colombia were selected as participants. Participants were randomly equally assigned to experiment group and control group. The writing proficiency of both groups was tested with a writing pre-test which was designed according to the Basic Skill Standards in Foreign Languages (Ministry of Education paperwork $N^{\circ} 22$ ) and no statistically significant difference was found between the groups of participants. During the implementation of the strategy the Experiment group was taught writing with picture series technique and the Process-based approach to determine whether the program of intervention achieved the intended results (cause and effect) concerning the research question to resolve the problem of investigation while the Control group was taught only with Process-based approach.

\subsection{Research Instruments to Collect the Data}

In collecting the data, the researchers applied two kinds of instruments: writing pre-test and writing post-test. Data extracted with these two instruments was assessed using a scoring rubric (Appendix A). The scoring rubric was adapted from the Michigan Educational Assessment Program (2011)

In the writing pre-test participants were asked to write a text without using picture series techniques and process writing steps to know students' skills in writing narrative text and determine baseline data before the intervention. The writing post-test was administered to evaluate overall growth, skill area development, measure the scopes of 
the intervention and compare gains within the population in order to establish how successful participant had been in relation to the expected effects.

The procedure to score the tests involved providing a copy of the test to each co-researcher for separated revision to avoid interference and researcher bias. Then, co-researchers met and discussed about each test, and finally, each individual test was given a definite score.

The students' writings were rated according to five main criteria: transition or logical sequence (use of connectors), exposition of ideas, grammar and syntax, vocabulary and word spelling. Each criterion had 20 points possible and scores on each scale were summed to obtain the total score (100 points possible). The classification of the system score that the researchers used in the rubric went from 0 to 100 as follows: Poor: 0-25; Low: 30-50; Average: 55-65; Good: 70-85; Very good: 90-100.

\subsection{Description of the Intervention}

The implementation of the strategy covered two academic terms in 2014. It was developed in three stages: pre-test, intervention, and post-test. The intervention stage held three times a week on Tuesday, Thursday and Friday, each section lasted 60 minutes covering 180 minutes of classroom work per week plus participants' independent work at home. This stage was concluded after 16 weeks. The intervention required the design of lesson plans that would fit the course and included explicit and implicit explanation, individual and group work, guided readings, vocabulary development and use, composition tasks, worksheets, among other activities carried out in class and at home. The language for instruction was mainly English, even though the researchers often switched to Spanish when it was needed to clarify some concepts participants found difficult to understand due to their language proficiency.

The writing pre-test was administered to both groups of participants in the first week, and then the mean scores were compared. It consisted of writing a narrative text from a picture in past tense. The intervention included a component of reading to make students familiar with different formats of narrative texts by using handouts of fables, short tales, review of movies, articles from magazines and newspapers. The decision of incorporating a reading component in all stages of this study is supported by the view of writing and reading as interrelated acts. Stotsky (1983) carried out a correlational inquiry that reviewed the literature on the relationship between reading and writing from 1930s to 1981. Her work found that studies to that time showed that good readers were often better writers over those who read less. It was also found that there was more gain in writing by incorporating reading than in place of grammar study or additional writing practice. Stotsky's view of reading is fully compatible with a number of studies in both first language and second language development from the 90's and beyond showing that those who read more acquire more of the written language (Lee, Krashen, \& Gribbons, 1996; Gradman \& Hanania, 1991)

During the intervention both, the Experimental group and the Control group were taught the five steps of the writing process namely prewriting, drafting, revising, editing and final draft. The rationale of adopting this process writing model is based on the combining features offered by the works of White and Arndt (1991), Flower and Hayes (1981) and (Graves, 1994) whose models seemed to be the most suitable for this study. Along with the process writing model selected, the researchers designed and applied tasks with picture series technique to the Experimental group. The nature of task followed the principle of Task-based language teaching or TBLT (Nunan, 1999) who, on the subject of pedagogical tasks, points out that "the ultimate rationale for language instruction is to enable learners to do things using language..." (p. 25).

The teaching of writing with Picture series technique basically followed the same format as described. The researcher introduced a text along with the picture portraying the action narrated in the reading. Participants read the text and identified those elements in the picture that helped in the structure of the reading like verbs, adjectives, nouns, characters among others. The researcher explained grammar and vocabulary use when needed and clarified concepts and ideas students were no familiar with.

Once the participants did the reading, they were provided with a task mainly about writing a narrative text from a picture series following the stages of writing. In the pre-writing stage they brainstormed the vocabulary (verb, noun, adjective, connectors, etc) to use by observing the picture series. They organized and planned the overall structure of the text: opening, development and resolution. They also identified the characters and their characteristic, the setting, the plot, and the theme. With all the data, participants proceeded to write the first draft. Once they completed the first draft, they shared with the class researcher and the co researchers, who provided proper feedback about general writing items (Appendix B provides samples of student's drafts with teacher comment and revision). After this stage was concluded, the students made corrections and refined their texts according to the observations the researcher and the co-researchers wrote on the revision sheet. (Appendix C). 
This sheet consists in a series of observations the researchers make on the students' drafts with different colors to high light aspects they need to improve in the text. Finally, after a process of preparing, drafting, correcting and re-rewriting, the participants were able to share the final version of their writing with their peers and teachers. Participants' artifacts were collected in a portfolio to enable both, the participants and the researchers, to reflect on the progress of participants' writing skills.

On the $16^{\text {th }}$ week of class sessions, the two groups wrote on the writing post-test, which had the same components of the writing pre-test. After the intervention stage the researchers analyzed the data they extracted from the instruments to assess the overall outcome of the intervention.

\section{Data Analysis, Findings and Discussion}

\subsection{Analysis of the Pre-Test and Findings}

The pre-test was intended to detect the basic writing skill of the students and it was given at the beginning of the intervention stage. It focused on the five components of narrative writing namely; transition or logical sequence (use of connectors), ideas (exposure), grammar and syntax (structure), vocabulary (use of parts of the speech), and word spelling contained in the scoring rubric. Both the Experimental group and the Control group were asked to write a composition in past tense. It consisted in writing about what a fictional character called did last weekend (Appendix D). Students were asked to brainstorm ideas for the composition, vocabulary regarding nouns, adjectives to describe characters and places, verbs according the actions depicted by the characters in the picture series strips, and connectors they needed for sequencing the actions. The size of the narration should not be longer than one and a half pages. The Experimental group, unlike the Control group, was provided with picture series. Once the groups finished the pre-test, the researchers proceeded to collect it and score it with the rubric. As can be seen, the scores of the Experimental group showed two (2) students with average performance, and eight (8) with low performance. On the other hand, the results from the Control group showed one (1) student with good performance, one (1) student with average performance, one student with poor performance and seven (7) students with low performance. Table 1 shows the pre-test scores for both groups as follows:

Table 1. Pre-test results of experimental and control groups

\begin{tabular}{llllll}
\hline Experimenta Group & Pre-test Score & Performance & Control Group & Pre-test Score & Performance \\
\hline S1 & 50 & Low & S1 & 35 & Low \\
S2 & 40 & Low & S2 & 45 & Low \\
S3 & 60 & Average & S3 & 30 & Low \\
S4 & 55 & Average & S4 & 55 & Average \\
S5 & Low & S5 & 45 & Low \\
S6 & 45 & Low & S6 & 50 & Low \\
S7 & 50 & Low & S7 & 50 & Low \\
S8 & 50 & Low & S8 & 25 & Poor \\
S9 & 40 & Low & S9 & 30 & Low \\
S10 & 50 & Low & S10 & 75 & Good \\
\hline
\end{tabular}

To calculate the pre-test Mean $(\bar{X})$ or average score (the resulting figure from the sum of individual scores (x) divided by the number of test-takers) the researchers applied the following statistical formula $\bar{X}=\sum x / n$, which symbols stand for: $(\bar{X})$ the mean or average, $\left(\sum\right)$ the sum that follows $(x)$ individual scores, and $(n)$ stands for the number of test-takers.

Experimental group pre-test Mean

$\bar{X}=\sum x / n$

$\bar{X}=485 / 10$

$\bar{X}=\mathbf{4 8 . 5}$

Control group pre-test Mean

$\bar{X}=\sum x / n$ 
$\bar{X}=440 / 10$

$\bar{X}=\mathbf{4 4}$

The Mean $(\bar{X})$ indicates that the test-takers from the Experimental group had an average score of 48.5 , which means that the group, as a whole, only got the $48.5 \%$ of 100 points possible ( 48.5 out of 100 ). On the other hand, The Mean $(\bar{X})$ of the Control group indicates that test-takers got $44 \%$ of 100 points possible (44 out of 100)

Once the Mean $(\bar{X})$ for both groups has been calculated, the next step is to calculate the standard deviation. For this, we subtract the mean from each score $(\mathrm{X}-\bar{X})$. What this operation represents is that we determine the distance (D) between each score and the mean score. Once that the distance has been calculated, the next step is to square each D value. Finally, we sum the D2 values and divide by the total number of test-taker minus one (1) to calculate the standard deviation (s) as expressed in the formula: $\mathrm{s}=\sqrt{ } \sum(\mathrm{x}-\bar{x}) / \mathrm{n}-1$. Table 2 and Table 3 portray the procedure to calculate the resulting standard deviation.

Table 2. Procedure to calculate the experimental group pre-test standard deviation(s)

\begin{tabular}{lllll}
\hline Students & Score $\mathrm{X}$ & Mean $\bar{X}$ & Distance $(\mathrm{D}) \mathrm{X}-\bar{X}$ & Distance squared $\left(\mathrm{D}^{2}\right)(\mathrm{X}-\bar{X})^{2}$ \\
\hline S1 & 50 & 48,5 & 1,5 & 2,25 \\
S2 & 40 & 48,5 & $(-8,5)$ & 72,25 \\
S3 & 60 & 48,5 & 11,5 & 132,25 \\
S4 & 55 & 48,5 & 6,5 & 42,25 \\
S5 & 45 & 48,5 & $(-3,5)$ & 12,25 \\
S6 & 50 & 48,5 & 1,5 & 2,25 \\
S7 & 50 & 48,5 & 1,5 & 2,25 \\
S8 & 40 & 48,5 & $(-8,5)$ & 72,25 \\
S9 & 50 & 48,5 & 1,5 & 2,25 \\
S10 & 45 & 48,5 & $(-3,5)$ & 12,25 \\
\hline
\end{tabular}

$\mathrm{s}=\sqrt{ } \sum(\mathrm{x}-\bar{x}) / \mathrm{n}-1$

$s=352.5 / 10-1$

$s=\sqrt{ } 39.17$

$\mathrm{s}=\mathbf{6 . 2 6}$

Table 3. Procedure to calculate the control group pre-test standard deviation(s)

\begin{tabular}{lllll}
\hline Students & Score $X$ & Mean $\bar{X}$ & Distance $(D) X-\bar{X}$ & Distance squared $\left(D^{2}\right)(X-\bar{X})^{2}$ \\
\hline S1 & 35 & 44 & $(-9)$ & 81 \\
S2 & 45 & 44 & 1 & 1 \\
S3 & 30 & 44 & $(-14)$ & 196 \\
S4 & 55 & 44 & 11 & 121 \\
S5 & 45 & 44 & 1 & 1 \\
S6 & 50 & 44 & 6 & 36 \\
S7 & 50 & 44 & 6 & 36 \\
S8 & 25 & 44 & $(-19)$ & 361 \\
S9 & 30 & 44 & $(-14)$ & 196 \\
S10 & 75 & 44 & 31 & 961 \\
\hline
\end{tabular}


$\mathrm{s}=\sqrt{ } \sum(\mathrm{x}-\bar{x}) / \mathrm{n}-1$

$s=1990 / 10-1$

$s=\sqrt{ } 221.1$

$s=\mathbf{1 4 . 8 7}$

The analysis of the standard deviation (s) in relation to the Mean $(\bar{X})$, in both groups, shows that individual scores were determining factors to categorize the groups as heterogeneous. For instance, the standard deviation (s) of the Experimental group is 6.26 away from the Mean (48.5). This statistical figure is due to those students who scored quite high (S3 and S4) and students who scored quite low (S2, S5, S8, S10) in comparison to the distance $(\mathrm{X}-\bar{X})$ between individual scores $(\mathrm{X})$ and the Mean $(\bar{X})$. On the other hand, the Control group shows a highest standard deviation $(\mathrm{s}=14.87)$ in relation to the Mean $(44)$. The distance $(\mathrm{X}-\bar{X})$ between individual scores (X) of students 4, 6, 7 and 10 and the Mean $(\bar{X})$ was the highest, while the distance $(\mathrm{X}-\bar{X})$ between students $1,3,8,9$ and the Mean $(\bar{X})$ was the lowest.

\subsection{Analysis of the Post-Test and Findings}

The post-test was given after intervention stage to the students. As in the pre-test, both the Experimental group and the Control group were asked to write a composition (Appendix E) in past tense and were given ninety minutes to finish the test. In the same way as in the pre-test, students were asked to brainstorm ideas for the composition, vocabulary regarding nouns, adjectives to describe characters and places, verbs according the actions depicted by the characters in the picture series strips, and connectors they needed for sequencing the actions, and keep the size of the narration (no longer than one and a half pages). The Experimental group, unlike the Control group, was provided with picture series. Once the groups finished the post-test, the researchers collected it, scored it with the rubric, and then analyzed the data.

The analysis of the post-test scores of the Experimental group showed that the amount of students with good performance was ten (10). On the other hand, the results from the Control group showed six (6) students with average performance, three (3) students with good performance and one (1) with very good performance. Table 4 illustrates the Pos-test scores for both groups as follows:

Table 4. Post-test results of experimental and control groups

\begin{tabular}{llllll}
\hline ExperimentalGroup & Post-test Score & Performance & Control Group & Post-test Score & Performance \\
\hline Student 1 & 80 & Good & Student 1 & 70 & Good \\
Student 2 & 70 & Good & Student 2 & 65 & Average \\
Student 3 & 80 & Good & Student 3 & 65 & Average \\
Student 4 & 75 & Good & Student 4 & 65 & Average \\
Student 5 & 80 & Good & Student 5 & 75 & Good \\
Student 6 & 80 & Good & Student 6 & 65 & Average \\
Student 7 & 70 & Good & Student 7 & 65 & Average \\
Student 8 & 85 & Good & Student 8 & 60 & Average \\
Student 9 & 85 & Good & Student 9 & 80 & Good \\
Student 10 & 75 & Good & Student 10 & 90 & Very good \\
\hline
\end{tabular}

To calculate the post-test Mean $(\bar{X})$ or average score the researchers applied the same procedures as in the pre-test.

Experimental group post-test Mean

$\bar{X}=\sum x / n$

$\bar{X}=780 / 10$

$\bar{X}=78$

Control group post-test Mean

$\bar{X}=\sum x / n$ 
$\bar{X}=700 / 10$

$\bar{X}=\mathbf{7 0}$

The Mean $(\bar{X})$ indicates that the test-takers from the Experimental group had an average score of 78 , which means that the group, as a whole, got the $78 \%$ of 100 points possible (78 out of 100$)$. On the other hand, the Mean $(\bar{X})$ of the Control group indicates that test-takers got $70 \%$ of 100 points possible (70 out of 100)

Table 5 and 6 portray the procedure to calculate the post-test distance squared $\left(\mathrm{D}^{2}\right)$ and the resulting standard deviation.

Table 5. Procedure to calculate the experimental group post-test standard deviation(s)

\begin{tabular}{lllll}
\hline Students & Score $X$ & Mean $\bar{X}$ & Distance $(D) X-\bar{X}$ & Distance squared $\left(D^{2}\right)(\mathrm{X}-\bar{X})^{2}$ \\
\hline S1 & 80 & 78 & 2 & 4 \\
S2 & 70 & 78 & $(-8)$ & 64 \\
S3 & 80 & 78 & 2 & 4 \\
S4 & 75 & 78 & $(-3)$ & 9 \\
S5 & 80 & 78 & 2 & 4 \\
S6 & 80 & 78 & 2 & 4 \\
S7 & 70 & 78 & $(-8)$ & 64 \\
S8 & 85 & 78 & 7 & 49 \\
S9 & 85 & 78 & 7 & 49 \\
S10 & 75 & 78 & $(-3)$ & 9 \\
\hline
\end{tabular}

$\mathrm{s}=\sqrt{ } \sum(\mathrm{x}-\bar{x}) / \mathrm{n}-1$

$s=260 / 10-1$

$s=\sqrt{ } 28.9$.

$\mathrm{s}=\mathbf{5 . 3 7 5}$

Table 6. Procedure to calculate the control group post-test standard deviation(s)

\begin{tabular}{lllll}
\hline Students & Score X & Mean $\bar{X}$ & Distance $(D) X-\bar{X}$ & Distance squared $\left(D^{2}\right)(\mathrm{X}-\bar{X})^{2}$ \\
\hline S1 & 70 & 70 & 0 & 0 \\
S2 & 65 & 70 & $(-5)$ & 25 \\
S3 & 65 & 70 & $(-5)$ & 25 \\
S4 & 65 & 70 & $(-5)$ & 25 \\
S5 & 75 & 70 & 5 & 25 \\
S6 & 65 & 70 & $(-5)$ & 25 \\
S7 & 65 & 70 & $(-5)$ & 25 \\
S8 & 60 & 70 & $(-10)$ & 100 \\
S9 & 80 & 70 & 10 & 100 \\
S10 & 90 & 70 & 20 & 400 \\
\hline
\end{tabular}

$\mathrm{s}=\sqrt{ } \sum(\mathrm{x}-\bar{x}) / \mathrm{n}-1$

$s=750 / 10-1$

$s=\sqrt{ } 83.33$

$\mathbf{s}=\mathbf{9 . 1 3}$ 
The researchers also found that, as in the pre-test, the standard deviation (s) shows that Experimental and Control groups are heterogeneous. For instance, the standard deviation (s) of the Experimental group is 5.375 away from the Mean (78). This is due to those students who scored quite high (S8 and S9) and students who scored quite low (S2, S4, S7, S10) in comparison to the distance $(\mathrm{X}-\bar{X})$ between individual scores $(\mathrm{X})$ and the Mean $(\bar{X})$. On the other hand, the Control group shows a highest standard deviation $(s=9.13)$ in relation to the Mean $(70)$. The distance $(\mathrm{X}-\bar{X})$ between individual scores $(\mathrm{X})$ of students 5,9 and 10 and the Mean $(\bar{X})$ was the highest, while the distance $(\mathrm{X}-\bar{X})$ between students $2,3,4,6,7,8$ and the Mean $(\bar{X})$ was the lowest.

\subsection{Comparative Analysis of Pre-Test and Post-Test Findings}

The average or mean scores of the Experimental group and the Control group pre-test were not statistically significant (48.5 and 45 in that order). Most of the students from both groups had low or poor performance ( $80 \%$ and $80 \%$ respectively). Only two students from the Experimental group had average performance, while the Control group had one student with average performance and one student with good performance and. This information pointed out that in general terms, participants' writing skill was quite deficient. With respect to the components of writing, both groups were statistically similar. The component of Vocabulary was the highest (120 and 100 correspondingly) while the component of Spelling was the lowest (70 and 75 in that order). The analysis of the rest of components showed that when writing, most of the students $(80 \%)$ in both groups had difficulties in structuring the logical sequence of their ideas. Those students from the Experimental group (students 3 and 4 ) and the Control group (students 4 and 10) that got average or good performances in the pre-test had already demonstrated better academic records in the subject before, in part because of the English courses they attended after school.

A comparative analysis of the findings from the pre-test and the post test revealed a significant growth in the average performance or mean of both groups. The Experimental group went from 48.5 to 78 , showing a growth of $37.83 \%$. On the other hand, the Control group went from 44 to 70 , with a total growth of $37.14 \%$. Table 7 shows the average score (mean) for each test and the percentage of growth.

Table 7. Pre-test and post-test mean (X) percentage of growth

\begin{tabular}{llll}
\hline \multicolumn{4}{l}{ Average score (mean) } \\
\hline Group of students & Pre-test & Post test & Growth \\
Experimental group & 48.5 & 78 & $37.82 \%$ \\
Control group & 44 & 70 & $37.14 \%$ \\
\hline
\end{tabular}

\subsection{Analysis of Groups' Performance in Each Component of Narrative Writing}

The researchers found that the pre-test score of writing components in the Experimental group showed that the highest components score of writing was vocabulary (120) while the lowest was for spelling (70). For the Control group, the highest score was vocabulary (100) while the lowest was for spelling (75). Graphics 1 and graphic 2 illustrate the writing components for each group.

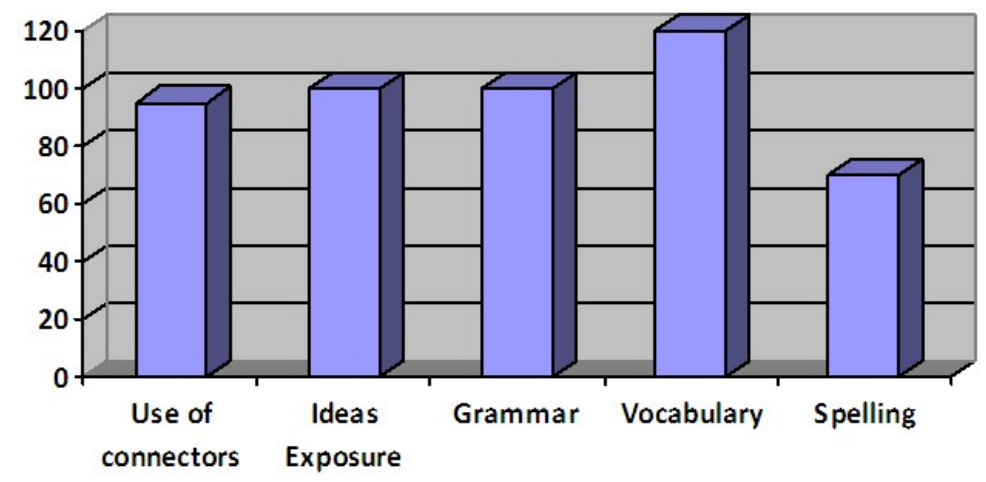

$\square$ Components

Graphic 1. Experimental group pre-test components of writing 


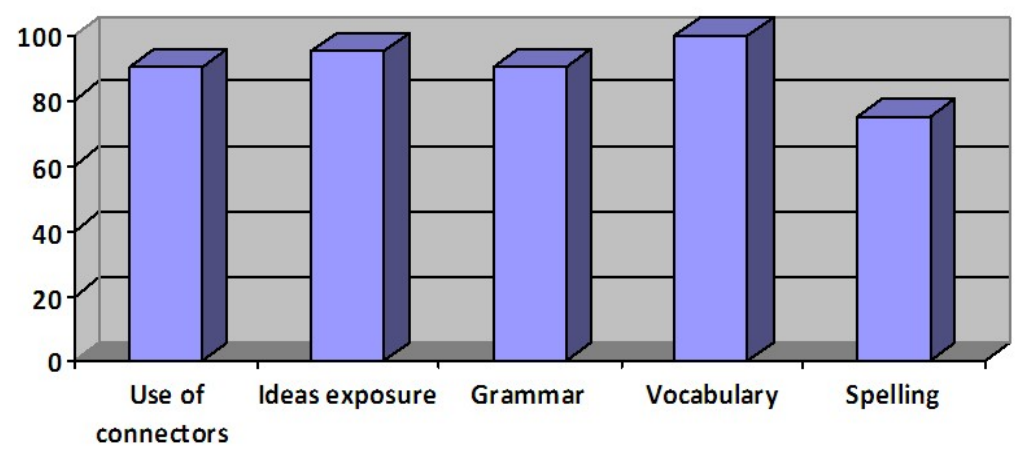

$\square$ Components

Graphic 2. Control group pre-test components of writing

The statistical analysis of the Experimental group's post-test evidenced that the highest components score of writing was for vocabulary (175), while the lowest was for spelling (130). For the Control group, the highest score was for transition or logical sequence and vocabulary (155) while the lowest was for spelling (105). Graphic 3 and 4 illustrate the writing components for each group.

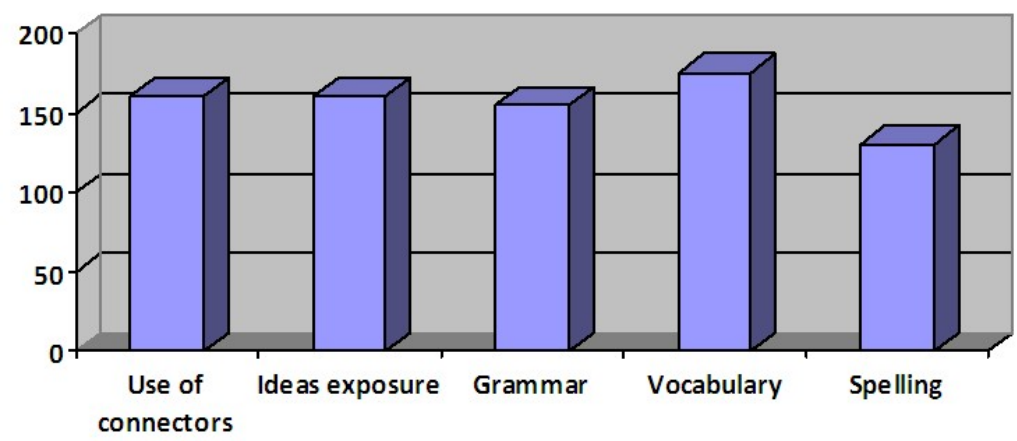

$\square$ Components

Graphic 3. Experimental group post-test components of writing

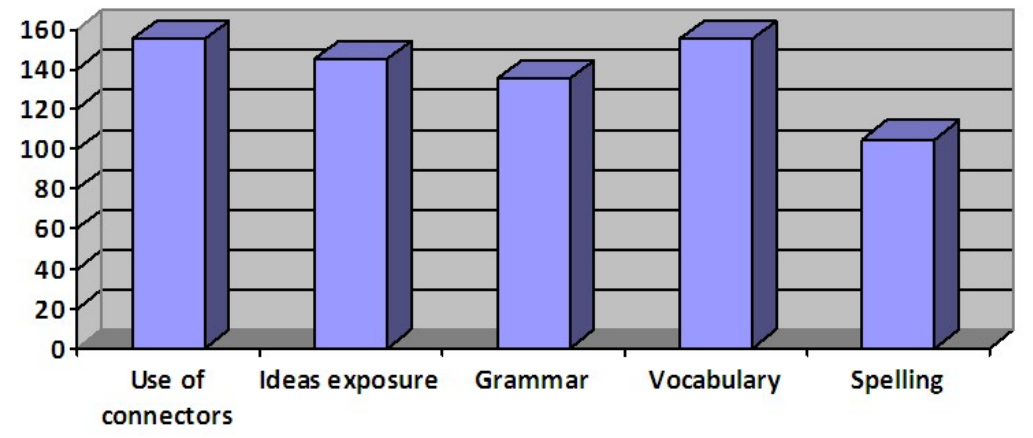

$\square$ Components

Graphic 4. Control group post-test components of writing

\subsection{Comparative Analysis between Pre-Test and Post-Test Writing Components}

The researchers also found that the results for each writing component in both groups had significant growth in the post-test. In the Experimental group, Spelling had the highest growth (46.15\%), even though, students' average score of Spelling in the pre-test and the post-test was the lowest (70 and 130 in that order). The component of Transition or Logical sequence had the second highest growth (40.63\%), Ideas exposure was in third place with $37.50 \%$, Grammar was in the fourth position with $35.48 \%$ while the component of Vocabulary had the lowest growth (31.43\%) but its average score in the pre-test and post-test was the highest (120 and 175 
respectively).

The Control group also evidenced significant growth in each writing component. The component of Transition or Logical sequence had the highest growth (41.94\%), Vocabulary was in second place with $35.48 \%$, Ideas exposure was third with $34.48 \%$, the fourth place was for Grammar with $33.33 \%$ while the component of Spelling had the lowest growth (28.57\%). Table 8 illustrates the figures and the percentage of growth.

Table 8. Comparative groups pre-test and post-test components of writing

\begin{tabular}{lllllll}
\hline \multirow{2}{*}{ Components } & \multicolumn{3}{l}{ Experimental group } & \multicolumn{3}{c}{ Control group } \\
\cline { 2 - 7 } & Pre-test & Post-test & Growth & Pre-test & Post-test & Growth \\
\hline Transition or logical sequence & 95 & 160 & $40,63 \%$ & 90 & 155 & $41,94 \%$ \\
Ideas exposure & 100 & 160 & $37,50 \%$ & 95 & 145 & $34,48 \%$ \\
Grammar & 100 & 155 & $35,48 \%$ & 90 & 135 & $33,33 \%$ \\
Vocabulary & 120 & 175 & $31,43 \%$ & 100 & 155 & $35,48 \%$ \\
Spelling & 70 & 130 & $46,15 \%$ & 75 & 105 & $28,57 \%$ \\
\hline
\end{tabular}

\subsection{Discussion of the Results}

This research project was aimed at establishing whether pictures series technique could improve narrative writing skills in a group of A2 CEFR proficiency level students. Based on the analysis of the data and the findings the researchers state that participants showed a marked improvement in their writing skills as a result of the implementation of Process writing. Even thought, the attained outcomes of this study reveal that subjects who were treated with pictures prompts outperformed students from the Control group who used the basic model of process approach writing. The researchers conclude that the intervention with Picture series technique improved the overall growth of writing skills, specific to the areas Transition or logical sequence and Ideas exposure. The subsequent discussion about the finding will support the statement above and enlighten the results from the data analysis.

The standard deviation (s) in both tests shows that the groups were heterogonous in their results, in which some students scored far above or far below the average or mean $(\bar{X})$. These individual results have an important implication in this study because students who scores above the average required less direction by the teachers/researchers during the intervention. This specific finding is coherent with the concept of Self-efficacy proposed by Bandura (1993). For Bandura, humans' beliefs about their capabilities play a crucial role in motivating human behaviors. People with high levels of self-efficacy, are likely to be more successful in different domains. On the other hand, those students who scored below the average in the Pre-test were encouraged and motivated to overcome their difficulties. For instance, during the process of intervention it was the teacher's responsibilities to motivate students with low level of academic performance by selecting the appropriate materials and methodology to captive students' engagement. As a result, motivated students were more willing to engage and succeed in writing and their scores improved significantly in the Post-test. This finding is in line with Schunk (1998) who holds that when students believe they are learning a useful strategy they develop Self-efficacy to improve their writing. Even though, in spite of this good academic particularities, the results of the Pre-test in both groups, show a low level of development in all components of narrative writing, since as a group, results did not match the minimum standards of language competence students in this grade are supposed to demonstrate according to the National Standards for Foreign Language Learning issued by The Ministry of Education in Colombia. This finding is hardly surprising, since, the writing skill does not develop naturally; it is quite challenging and students require time to achieve acceptable levels of written performance. This data became the point of departure to initiate a process of investigation intended to improve the narrative writing skill in the groups of participants.

Another important finding arose from the comparative analysis between the results from the Pre-test and the Post-test, which evidences a very interesting behavior of the participants, before and after the process of intervention. The researchers observed that the average performance of the Experimental and Control group increased substantially ( $37.82 \%$ and $37.14 \%$ respectively) as well as the five components the study selected as fundamental for narrative writing: Transition or logical sequence (use of connectors), Exposition of ideas, Grammar and Syntax, Vocabulary and Word spelling as shown in Table 8 . These results prove that participants 
were willing to adopt the strategy of following a series of stages to finally produce a better polished piece of written work. This finding is consistent with Nunan (1999) who introduces Process approach according to steps involved in drafting and redrafting a piece of work. For Nunan, writing is an active process of "producing, reflecting on, discussing and reworking successive drafts of a text" (p. 272).

The data analysis also revealed that the Experimental group had an overall improvement of EFL narrative writing components in favor of the post-test, where it is observed a growth of $37.82 \%$. Scores went from $80 \%$ of participants in low performance to $100 \%$ of participants in good performance. Spelling, logical sequence and ideas exposure were the components of narrative writing criteria that obtained the highest significant growth in the Post-test, while vocabulary and grammar had the lower evidence of increase. The behavior of how particularly two components improved in the produced texts (logical sequence and ideas exposure) led the researchers imply that the nature of the strategy allowed participants from the Experimental group to focus on the function of the type of the required text, telling stories. This evidence supports the claims of Morrison.et al (2002) who states that the stimuli pictures story brings to the writing class enhances cognitive processes that support the development of idea sequencing and therefore make students comply with the rhetorical structure of narrative texts. On the other hand, it is important to note that although the Control group subjects showed a $37.14 \%$ difference from Pre-test to Post-test performance, researchers report that some students from this group kept relying on previous patterns of use of connectors and linkers specially those the leader teacher had already taught as part of the school syllabus. Students with the picture for their part, showed an interest for the search and use of new connectors and transitional words as evidenced in the preparation stage kept in the portfolios.

The researchers also found that pictures technique may enhance the students' cognitive process of noticing the logical connections between the events in the story and therefore the search for the proper words to represent those connections. Although no specific literature has been found to relate picture technique and its impact on connectors or linkers use, this study can shed light on answers to the concern raised by Ghasemi, (2013) in regards to the need for specific strategies to enhance the learning and teaching of cohesive device in L2 writing.

Findings related to growth of Vocabulary and Grammar revealed that the Experimental group over performed the Control group in this components. It seems that pictures helped students increase their vocabulary usage by utilizing words that explained and evaluated the pictures and also providing visual feedback of the objects and actions portrayed in them. This results are consistent with the work of Raimes (1983) who quotes that "all students after close observation of the material (pictures), will immediately need the appropriate vocabulary, idiom and sentences structures to discuss what they see" (p. 27).

Finally, findings revealed that the use of Pictures series technique made more effective the Process approach implemented in the groups. There was a marked improvement in the overall writing skills of the targeted population using Picture series technique. Participants improved their sequencing skills by writing stories in chronological order with details and consistent use of time-order words. Finding that is in line with, Raimes (1983) who states that "A picture sequence, such as a comic strip, provides the subject matter for writing narrative and for speculating about the story beyond the pictures in the strip" (p. 28).

\section{Conclusion}

In conclusion, Pictures series technique applied to Process approach was a suitable strategy for EFL students from the eighth grade at Institución Educativa Simón Araujo to increase their narrative skill in English. In addition, this type of resources was a means for increasing students' motivation to improve and practice their narrative writing skills.

\section{Limitations and Suggestions for Further Studies}

Given that it was the first time such a project had been implemented, the recentness of the strategy may have affected students' affective filter at the beginning of the sessions and consequently the results in the Pre-test. Hence, this research could be replicated allocating a certain time prior to the intervention in which participants could get accustomed to the stages the process approach requires before implementing the intervention.

Although the nature of the project required Experimental and Control groups to measures the scopes of the intervention, restriction of time factor left little space for researchers to level the Control group student with the students from the target group at the end of the academic term. Further studies should open a space of time for all students may benefit from the strategy.

In the light of previous results from the data analysis and finding, the researchers recommend the use of Picture series technique and Process approach across all grade levels of tuitions. The versatility if the strategy makes it suitable to be implemented with students from all grades, covering a high diversity of topics and skills. 
It is also recommended for classroom teachers integrate Picture series technique when designing resources and material for tuitions and learning. Applying pictures increases the chance of the developing communicative skills and the appropriation of the content and topics of the class. Beside, the resourcefulness of pictures and images reduce the limitations in contexts wherein resources for teaching are very limited or scarce.

\section{References}

Abbott, P. H. (2002). The Cambridge introduction to narrative. Cambridge: Cambridge University Press.

Alvarez, C. (2013). Fostering self-efficacy for descriptive writing in a group of A1 adolescent learners through the use of learning logs (Master thesis, Universidad de la Sabana. Chía, Cundinamarca, Colombia).

Aschawir, A. (2014). Using series pictures to develop the students' ideas in English narrative writing. Scholarly Journal of Education, 88-94.

Bandura. (1993). Perceived self-efficacy in cognitive development and functioning. Journal of Educational Psychology, 28, 117-148. http://dx.doi.org/10.1207/s15326985ep2802_3

Barbe, W. B., \& Milone, M. N. (1981). What we know about modality strengths. Educational Leadership, 378-380.

Bowen, B. M. (1991). Look here! Visual aids in language teaching. London: Modern English Publishers.

Brown, D. H. (2000). Principles of language learning and teaching. New York: Longman, 4th Edition.

Carr, W., \& Kemmis, S. (1986). Becoming critical. Education, knowlege and action reseach. New York: Deakin University Press.

Díaz, Á. (1999). Aproximación al texto escrito. Medellin: Editorial universidad de Antioquia.

Dunn, R., \& Dunn, K. (1992). Teaching students through their individual learning styles. Boston: Allyn \& Bacon.

Fleming, N. (2001). Teaching and learning styles: VARK strategies. Christchurch, New Zealand: Published by the author.

Flower, L. S., \& Hayes, J. R. (1981). A cognitive process theory of writing. College Composition. http://dx.doi.org/10.2307/356600

Ghasemi, M. (2013). An investigation into the use of cohesive devices in second language writings. Theory and Practice in Language Studies, 1615-1623.

Gradman, H. L., \& Hanania, E. (1991). Language learning background factors and ESL proficiency. Modern Language Journal, 39-51. http://dx.doi.org/10.1111/j.1540-4781.1991.tb01081.x

Graves, D. (1994). A fresh look at writing. Portsmouth: Heinemann.

Harmer, J. (2004). How to teach writing. England: Pearson Education.

Hasan, K., \& Akhand, M. M. (2010). Approaches to writing in EFL/ESL context: Balancing product andpProcess in writing class at tertiary level. Journal of NELTA, 77-88.

Hedge, T. (2005). Writing. Oxford: Oxford University Press.

Hill, D. A. (1990). Visual Impact. Creative language learning through pictures. London: Longman Group UK limited.

Konomi, D. K. (2014). Using visual materials in teaching vocabulary in English as a Foreign. International Conference: New Perspective in Science and Education, 254-259.

Krashen, S. (1981). Principle and practices in second Language Learning. Oxford: Pergamon.

Kroll, B. (1990). Second language writing: Research insights for the classroom. Cambridge: Cambridge University Press. http://dx.doi.org/10.1017/CBO9781139524551

Lee, Y. O., Krashen, S., \& Gribbons, B. (1996). The effect of reading on the acquisition of English relative clauses. ITL: Review of Applied Linguistics, 113-114, 263-273.

Mansourzadeh, N. (2014). A comparative study of teaching vocabulary through pictures and audio-visual aids to young Iranian EFL learners. Journal of Elementary Education, 47-59.

Morrison, T., Bryan, G., \& Chilcoat, G. W. (2002). Using student-generated comic books in the classroom. Journal of Adolescent and Adult Literacy, 45(8), 758-767. 
Nunan, D. (1999). Second language teaching and learning. Boston: Heinle.

Raimes, A. (1983). Techniques in teaching writing. Cambridge: Oxford University Press.

Reid, J. (2001). Writing. In R. Carter, \& D. Nunan (Ed.), Teaching english to Speaking of Other Languages (pp. 28-33). Cambriedge: Cambriedge University Press.

Richard, J. C. (1990). The language teaching matrix. New York: Cambriedge University Press. http://dx.doi.org/10.1017/CBO9780511667152

Sa'diyah, H. (2010). Improving students' ability in writing descriptive texts through a picture series aided learning strategy. The English Teacher, 164-182.

Sasaki, M. (2000). Toward an empirical model of EFL writing processes: An exploratory study. Journal of Secoind Language Writing, 259-291. http://dx.doi.org/10.1016/S1060-3743(00)00028-X

Schunk, D. H. (1998). Teaching elementary students to self-regulate practice of mathematical skills with modeling. In D. H. Schunk, \& B. J. Zimmerman (Ed.), Self-regulated learning: From teaching to self-reflective practice (pp. 137-159). New York: The Guilford Press.

Silva, T., \& Matsuda, P. (2001). On second language writing. Mahwah, NJ: Lawrence Erlbaum.

Stotsky, S. (1983). Research on reading /writing relationships: A synthesis and suggested directions. Language Arts, 627-642.

Uematsu, H. (2012). The use of pictures and illustrations in teaching English. 21st Century Education Forum, 45-50.

White, R., \& Arndt, V. (1991). Process writing. London: Longman.

Wright, A. (1990). Pictures for language learning. Cambridge: Cambridge University Press.

\section{Appendix A}

Adapted rubric for narrative writing scoring

Narrative Writing Scoring Rubric

\begin{tabular}{|c|c|c|c|c|c|}
\hline & Criteria & 5 & 10 & 15 & 20 \\
\hline 1 & $\begin{array}{l}\text { Transition } \\
\text { or logical } \\
\text { sequence } \\
\text { (Use of } \\
\text { connectors) }\end{array}$ & $\begin{array}{l}\text { Lack or minimal } \\
\text { use of connective } \\
\text { and conjunctions }\end{array}$ & $\begin{array}{l}\text { The writer uses } \\
\text { small selection of } \\
\text { simple } \\
\text { connectives and } \\
\text { conjunctions }\end{array}$ & $\begin{array}{l}\text { The writer uses } \\
\text { connectives words } \\
\text { properly }\end{array}$ & $\begin{array}{l}\text { The writer uses } \\
\text { connectives words } \\
\text { properly and the } \\
\text { meaning of the text is } \\
\text { clear and flows well in } \\
\text { a sustained piece of } \\
\text { writing }\end{array}$ \\
\hline 2 & $\begin{array}{l}\text { Ideas } \\
\text { exposure }\end{array}$ & $\begin{array}{l}\text { Ideas are not } \\
\text { focused on the } \\
\text { task and/or are } \\
\text { undeveloped. }\end{array}$ & $\begin{array}{l}\text { Tells a story with } \\
\text { ideas that are } \\
\text { minimally focused } \\
\text { on the topic and } \\
\text { developed with } \\
\text { limited details. }\end{array}$ & $\begin{array}{l}\text { Tells a story with } \\
\text { ideas that are } \\
\text { somewhat focused on } \\
\text { the topic and are } \\
\text { developed with a mix } \\
\text { of specific and/or } \\
\text { general details. }\end{array}$ & $\begin{array}{l}\text { Tells a story with } \\
\text { ideas that are } \\
\text { somewhat focused on } \\
\text { the topic and are } \\
\text { developed with a mix } \\
\text { of specific and/or } \\
\text { general details. }\end{array}$ \\
\hline 3 & $\begin{array}{l}\text { Grammar } \\
\text { and syntax }\end{array}$ & $\begin{array}{l}\text { Do not keep the } \\
\text { basic structure of } \\
\text { a sentence and } \\
\text { most of verbs are } \\
\text { not inflexed }\end{array}$ & $\begin{array}{l}\text { Keep the basic } \\
\text { structure of a } \\
\text { sentence bur verbs } \\
\text { are not inflexed } \\
\text { properly or are } \\
\text { wrongly used }\end{array}$ & $\begin{array}{l}\text { Keep the basic } \\
\text { structure of a sentence } \\
\text { but still misses the } \\
\text { distinction between } \\
\text { regular and irregular } \\
\text { verbs (generalization } \\
\text { of the regular case } \\
\text { rule for all verbs) }\end{array}$ & $\begin{array}{l}\text { Keep the basic } \\
\text { structure of a sentence } \\
\text { and distinguishes } \\
\text { between regular and } \\
\text { irregular verbs }\end{array}$ \\
\hline 4 & Vocabulary & Use of imprecise & Ineffective use of & Clear use of precise & Compelling use of \\
\hline
\end{tabular}




\begin{tabular}{|c|c|c|c|c|c|}
\hline & & $\begin{array}{l}\text { language and } \\
\text { weak vocabulary }\end{array}$ & $\begin{array}{l}\text { precise language } \\
\text { and vocabulary }\end{array}$ & $\begin{array}{ll}\text { language } & \text { and } \\
\text { vocabulary } & \end{array}$ & $\begin{array}{l}\text { precise language and } \\
\text { vocabulary }\end{array}$ \\
\hline 5 & Spelling & Numerous errors & Several errors & Few errors & Minimal errors \\
\hline
\end{tabular}

\section{Description of criteria}

* Transition or logical sequence: it refers to how the write uses transitional words or connectors to join the events portrayed in the pictures.

* Ideas exposure: It refers to how the writer exposes the ideas regarding the topic

* Grammar and syntax: it refers to the structures of sentences (syntax) and correct inflexion of verbs

* Vocabulary: The range and precision of language choices

* Spelling: The accuracy of spelling and the difficulty of the words used.

\section{Appendix B}

Samples of student's drafts with teacher comment and revision.
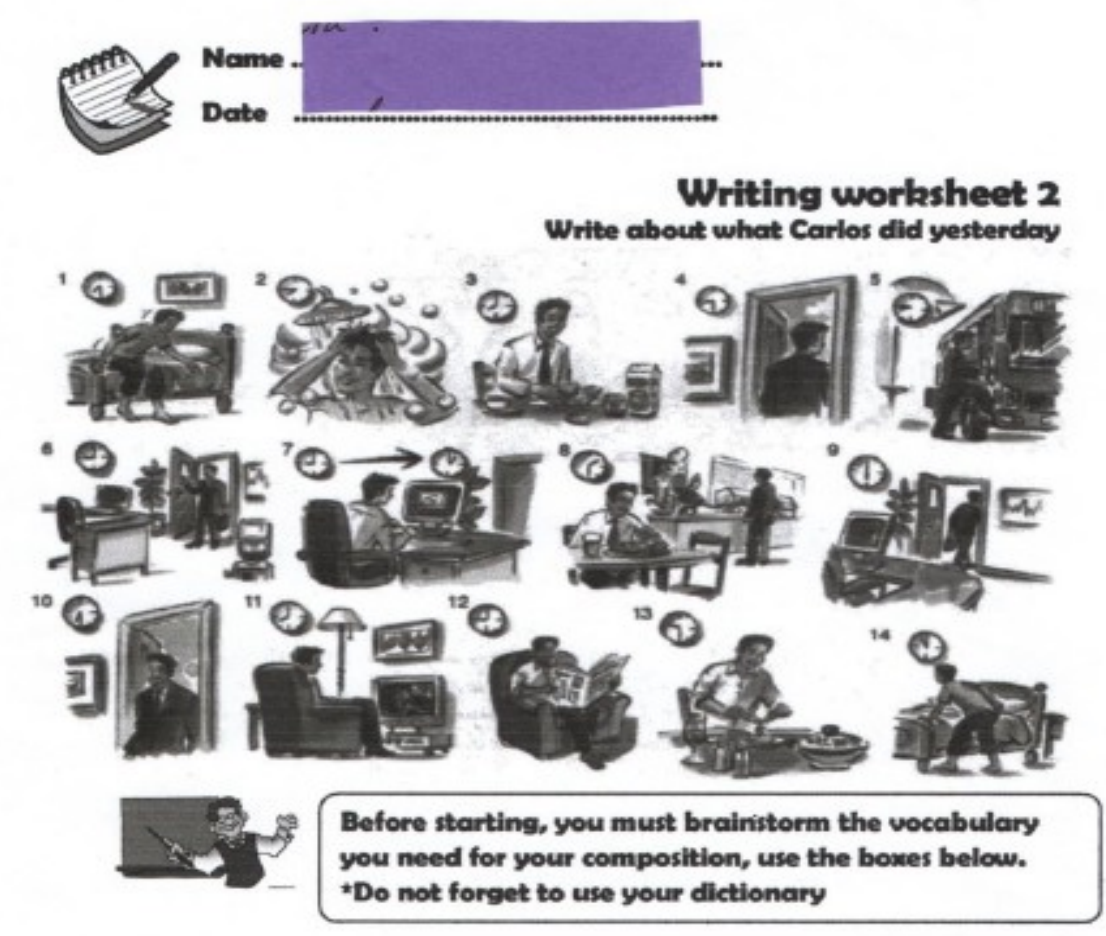

\begin{tabular}{|c|c|c|}
\hline Verbs & Connectos & Vocabulary in general \\
\hline $\begin{array}{l}\text { Raise of the bed, Take } \\
\text { a shower, have the } \\
\text { breakfast, go to work } \\
\text { take the bus, enter the } \\
\text { office, work in the } \\
\text { computer, have the } \\
\text { lunch, go off the offi- } \\
\text { ce, arrive to the house } \\
\text { see the T.V. read the }\end{array}$ & $\begin{array}{l}\text { And-after-later } \\
\text { then, First, Finally }\end{array}$ & $\begin{array}{l}\text { Office - Cafeteria- } \\
\text { restaurante-computer } \\
\text { bathroom-clock. } \\
\text { lamp-movie. }\end{array}$ \\
\hline
\end{tabular}




\section{WRITING WORKSHEET 1}

\section{DRAFT $\neq 1$}

Carlos raised of the bed, he took a shower and he had the breakfast in the kitchen. Carlos went to work and he Took the bus. He entered the office and he work on the computer. In the midday Carlos has the lunch in the restaurante. Carlos go off the office and enter the home.

Carlos saw the T.viread the newspaper and had the diner. Finally Carlos went to sleep on the bed.

\section{Comments}

Dear student correct the rext with the observation in color.

Suggestion.

For second droft. Write with more de tails, be more creative and portray more actions to your text

Prepare second droft.

\begin{tabular}{|c|c|}
\hline & $\begin{array}{l}\text { Check the color and malke all corrections according to the obscrvations } \\
\text { Observa los colores y haz las correcciones de acuerdo a las observaciones }\end{array}$ \\
\hline & $\begin{array}{l}\text { Check word spelling, } \\
\text { Revise la ortografia de la palabra }\end{array}$ \\
\hline 8 & $\begin{array}{l}\text { Verbs are wrongly conjugated, change verb tense } \\
\text { El verbo está mal conjugado, cambie el tiempo verbal }\end{array}$ \\
\hline 2 & $\begin{array}{l}\text { Lack of scise } \\
\text { A la oración le falta sentido }\end{array}$ \\
\hline & $\begin{array}{l}\text { Missing connector } \\
\text { Falta el conector }\end{array}$ \\
\hline 48 & $\begin{array}{l}\text { Falta el conector } \\
\text { Wrong word } \\
\text { Palabra equivocada }\end{array}$ \\
\hline & $\begin{array}{l}\text { Wrong sentence order. Check syntax } \\
\text { Orden incorrecto de la oración, revise la sintaxis }\end{array}$ \\
\hline 28 & $\begin{array}{l}\text { Excessive use of words, use synonyms } \\
\text { Uso excesivo de la misma palabra, use sinónimos }\end{array}$ \\
\hline$X$ & $\begin{array}{l}\text { Omit unnerescary wond } \\
\text { Omita palabra innecesaria }\end{array}$ \\
\hline
\end{tabular}


www.ccsenet.org/elt

English Language Teaching

Vol. 8, No. 5; 2015

WRING WORKSHEET '
DRAFT 2

Carlos wore up early, Carlos took a shower and he had breakfast in the chicken. Carlos went to work and he took the bus. he arrived to the office and he work in the computer and he had lunch in the restaurant. Carlos left the office and he went to the home.

In the home carlos watching the TV/ he reads the newspaipery he had dinner and he went to the bed to sleeping.

Dear student cheek the revision sheet again and comet the mistakes.

there is still something to correct BUT DON'T Works you are doing a good work. Please follow my comments and be ready for next draft.

Comments.

- Look at the Clock in each picture. It has the time for every action.

- Include more actions and your paper will be better. I want to read next draft!?!

Your Teacher.

64 
www.ccsenet.org/elt

English Language Teaching

Vol. 8, No. 5; 2015

$$
\begin{aligned}
& \text { WRITING WORKSHEET } \\
& \text { DRAFT } \text { \& } 3
\end{aligned}
$$

Carlos woke up at 7:30 A.M. He took a shower, got dressed and then he had breakfast in the kitchen.

At 8:30 Carlos went to work, he took the bus at 8:45. Later Carlos arrived at the office and he worked on the computer From 9:00 A., to 1:00 P.M. Carlos, more later, had lunch in the restaurant. for half hour.

Carlos worked all afternoon in the office, from 1:30 to 6:00 P.M. Af 6:00 P. II Carbs left the office and he went home. Carlos relaxed in Front of the T.V. Carlos watched his Favorite TV. program. "Wo and a hat man". After that Carlos read the newspaper from 9:00 P.H to 9:30. At 9:30 Carlos had dinner and Finally the went to bed at 11:00 P,H.

END

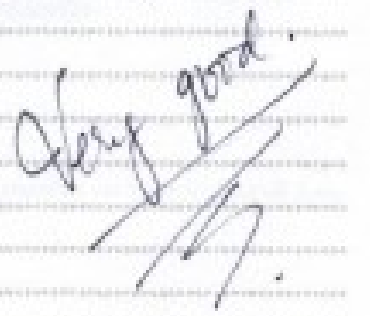

Congratulation. Yo r hare made less mistakes and your draft is better now. You are just one step to and. please comet the mistakes and write the finolvedion.

65 


\section{Appendix C}

Sample of revision sheet

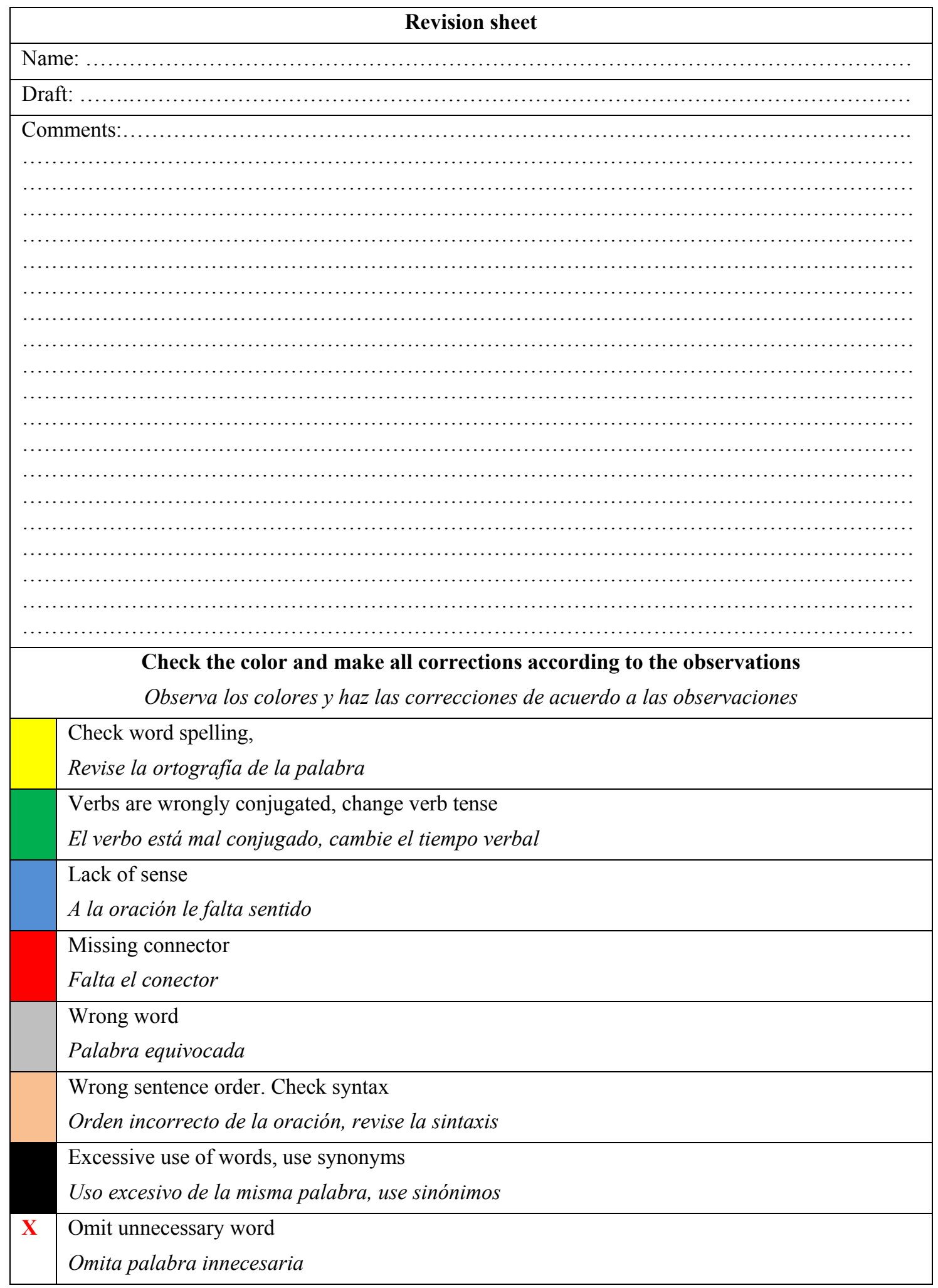




\section{Appendix D}

Sample of student's Pre-test with teacher comment and revision

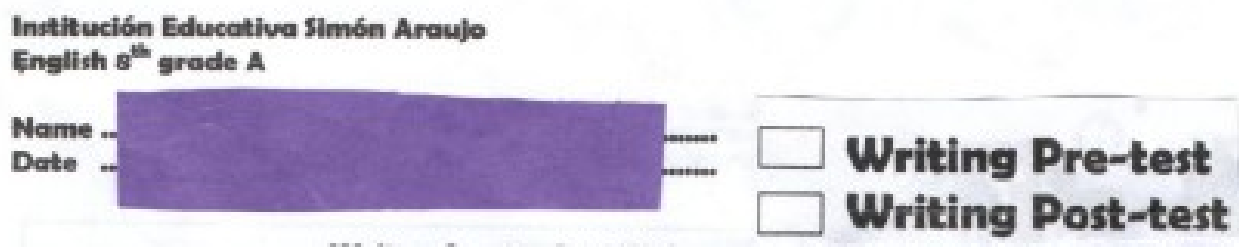

Write about what Ricky, a rock star, did on last weekend.

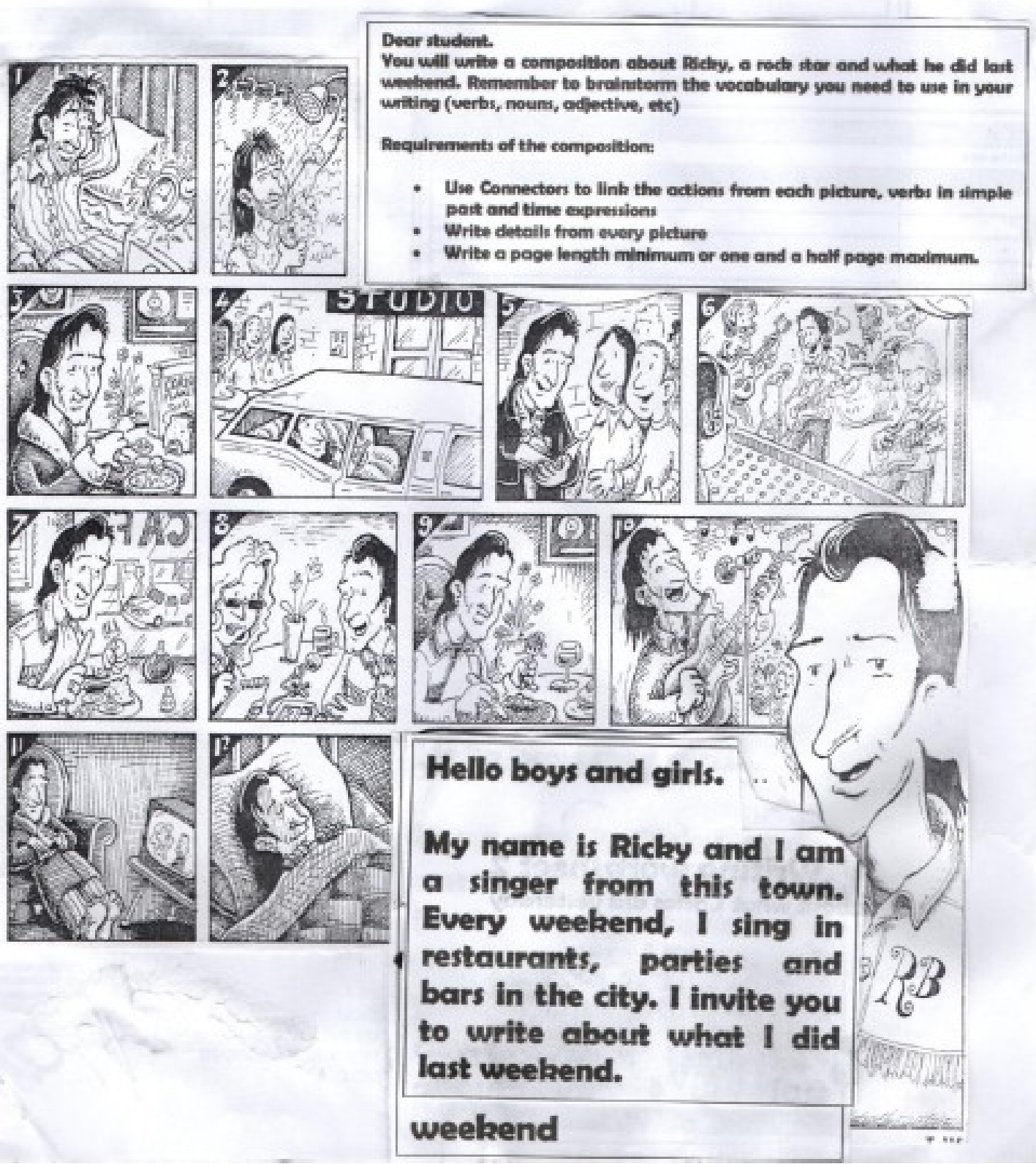




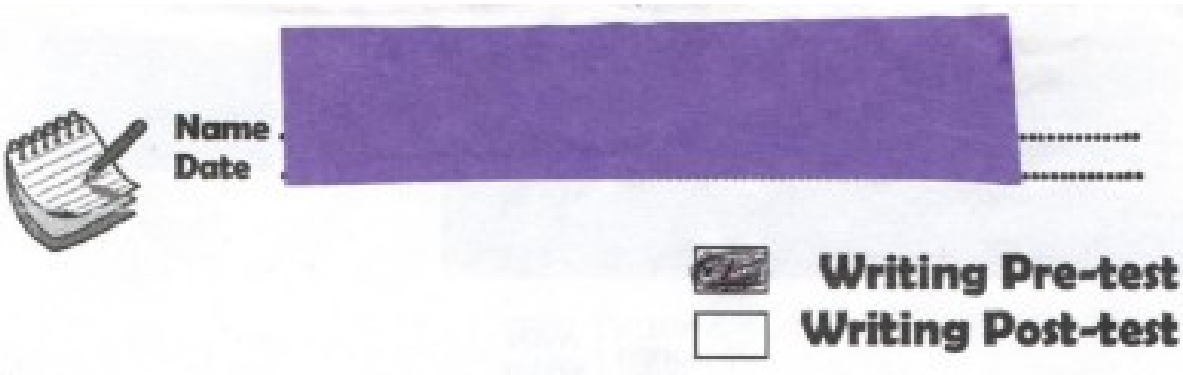

(1) Verbs=get up - Take a shower - have the breakfast-go in the car - Write on the notebook - sing and play musik have the lunch-speak - have the dinner-sing See T.V-go to sleep on the bed

(2) Connectors = and-after-fist-leiter-finalyafter than

(3) Time expresions = in the morning - in the afternoon in the night.

Write about what Ricky a rock star did on last weekend

Fist Ricky getted up, he taked a shower and he has breakfastoricky went in the car and he (likgo) to studio Ricky wrted on the notebook from the peoples and he

sung musik and he played the guitarr. He has breakfast in the restauranteg he speaked with a woman in the restaurante. In the afternoon he has diner and leiter he sung and played the guitarr with friends. Ricky goes to the home and saw the T.V and goed to sleep on the bed. 


\section{Pre-test Revision sheet}

Name:

Comments:

\section{Reviewer 1:}

Subject got the idea about what to write, even though, he makes spelling mistakes, and hardly know how to conjugate verbs in simple past.

\section{Reviewer 2:}

Subject know about what to write about, but he has problems about how to connect ideas (he misses connectors or linkers) there are some spelling problems, but nothing important to worry about. Leader teacher should emphasis in the finding from the pre-test.

\section{External reviewer:}

Subject shows weakness in conjugating verb in simple past, he misses connectors and the over uses few of them. Spelling should be treated with dictionary and reading.

\section{Check the color and make all corrections according to the observations}

Observa los colores y haz las correcciones de acuerdo a las observaciones

\begin{tabular}{|l|l|}
\hline & $\begin{array}{l}\text { Check word spelling, } \\
\text { Revise la ortografia de la palabra }\end{array}$ \\
\hline El verbo está mal conjugado, cambie el tiempo verbal \\
\hline $\begin{array}{l}\text { Lack of sense } \\
\text { A la oración le falta sentido }\end{array}$ \\
\hline $\begin{array}{l}\text { Missing connector } \\
\text { Falta el conector }\end{array}$ \\
\hline $\begin{array}{l}\text { Wrong word } \\
\text { Palabra equivocada }\end{array}$ \\
\hline Wrong sentence order. Check syntax \\
Orden incorrecto de la oración, revise la sintaxis \\
\hline $\mathbf{X}$ & $\begin{array}{l}\text { Excessive use of words, use synonyms } \\
\text { Oso excesivo de la misma palabra, use sinónimos }\end{array}$ \\
\hline
\end{tabular}




\section{Appendix E}

Sample of student's Post-test with teacher comment and revision

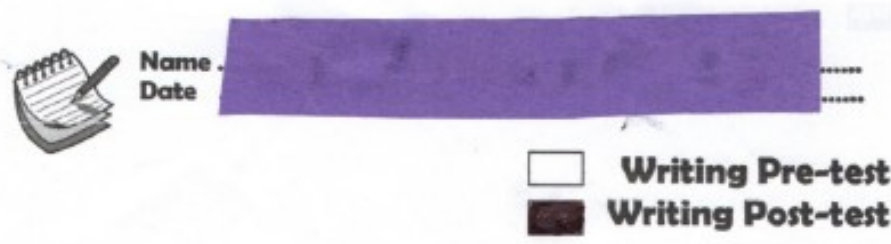

(1) Verbs = get up-Take a shower-have breakfast-go by car to the studiw.sign autographs, play and sing with the band. have lunch - Talk to a woman For interview - have dinner Sing in the concert - watch TV-go to sleep.

(2) connectors = First, later, then, after, after that, Finally, and.

(3) Time expressions = in the morning - in the afternoonoo at night.

(4) Places-house-cafeteria/restaurant-studiu-stadiom street.

Write about what Ricky, a rock star, did on last weekend. Ricky got up late at 9:00 A.M. then he took a Shower in the bathroom and got dressed and later he had breakfast. Ricky had Cereal and bread for breakfast. Ricky went to the studio by car (limosina) Ricky signed autographs for the people on the street. Ricky. later sang and played music with his band in the studio $\Longrightarrow$

At noon Ricky has lunch in the restaurant,
the lunch was very good. Ricky had beans, eggs
rice and chicken. After that Ricky talked
to a woman for interview on the recorder.
Later, in the afternoon. Ricky went home
and had dinner. Ricky ate pasta and drank
wine.
At night, Ricky sang and played music
in the concert in the stadium For 2 hours.
At night Ricky went home and watdied.
T.V for 1 . hours. Ricky was tired for the
concert and Ricky went to sleep.
End.




\section{Post-test Revision sheet}

Name:

Comments:

\section{Reviewer 1:}

Very few spelling mistakes, subject has improved in developing ideas, verb are good conjugated and there is more variety of connectors.

\section{Reviewer 2:}

Subject has improved writing, there are just 2 o 3 mistakes, but in general there is a lot of improvement from pre-test to post-test.

\section{External reviewer:}

Subject has assimilated the strategy, the revision of the pre-test showed several mistakes, even though, post test results are much better. There is a lot of gain in ideas exposure, connecting ideas, spelling and grammar of verb in simple past.

\section{Check the color and make all corrections according to the observations}

Observa los colores y haz las correcciones de acuerdo a las observaciones

\begin{tabular}{|l|l|}
\hline & $\begin{array}{l}\text { Check word spelling, } \\
\text { Revise la ortografia de la palabra }\end{array}$ \\
\hline El verbo está mal conjugado, cambie el tiempo verbal \\
\hline $\begin{array}{l}\text { Lack of sense } \\
\text { A la oración le falta sentido }\end{array}$ \\
\hline $\begin{array}{l}\text { Missing connector } \\
\text { Falta el conector }\end{array}$ \\
\hline $\begin{array}{l}\text { Wrong word } \\
\text { Palabra equivocada }\end{array}$ \\
\hline $\begin{array}{l}\text { Wrong sentence order. Check syntax } \\
\text { Orden incorrecto de la oración, revise la sintaxis }\end{array}$ \\
\hline $\mathbf{X}$ & $\begin{array}{l}\text { Excessive use of words, use synonyms } \\
\text { Oso excesivo de la misma palabra, use sinónimos }\end{array}$ \\
\hline
\end{tabular}

\section{Copyrights}

Copyright for this article is retained by the author(s), with first publication rights granted to the journal.

This is an open-access article distributed under the terms and conditions of the Creative Commons Attribution license (http://creativecommons.org/licenses/by/3.0/). 